DOI: https://doi.org/10.32838/2523-4803/70-6-14

удК 65.012:614.2

\title{
Ягельська К.Ю.
}

доктор економічних наук, доцент,

Донецький національний технічний університет

Yahelska Kateryna

Donetsk National Technical University

\section{ОРГАНІЗАЦІЙНО-ЕКОНОМІЧНІ ОСОБЛИВОСТІ ТРАНСФОРМАЦЙНОЇ МОДЕЛІ ОХОРОНИ ЗДОРОВ'Я УКРАЇНИ}

\begin{abstract}
У статті розглянуто світовий досвід організації систем фінансування охорони здоров'я та етапи реформування вітчизняної моделі надання медичних послуг. Узагальнено результати опитування населення щзодо реалізації медичної реформи. Проведено SWOT-аналіз вітчизняної трансформаиійної моделі державного солідарного медичного страхування, в результаті чого визначено організаиіийн-економічні особливості, переваги і недоліки діючої системи охорони здоров'я Украӥни. 3 'ясовано найсильніші та найслабші сторони вітчизняної моделі, а також ії тимчасові проблеми. Розглянуто причини недостатнього фінансування медичної галузі та зроблено висновок щзодо необхідності коригування плану реформування. Визначено напрями та окреслено основні шляхи удосконалення діючої системи охорони здоров'я за рахунок мінімізації протиріч в оновленій моделі.
\end{abstract}

Ключові слова: охорона здоров'я, модель, фінансування, SWOT-аналіз, напрями удосконалення.

Постановка проблеми. Питання оптимізації витрат суспільства на розвиток системи охорони здоров'я в суперечливих умовах сьогодення набувають соціально-економічної значущості. Всупереч усвідомленню необхідності інвестицій у здоров'я населення як стратегічно важливого чинника розвитку країни, практична реалізація заходів з організації охорони здоров'я в процесі реформування іiі системи стикається з низкою перешкод, пов'язаних із недосконалим управлінням галуззю, неефективними механізмами економічної взаємодії, недостатніми джерелами фінансування, їх нераціональним співвідношенням та розподіленням коштів. Зазначене актуалізує пошуки напрямів та способів удосконалення вітчизняної системи охорони здоров'я на сучасному етапі іiі трансформації.

Аналіз останніх досліджень і публікацій. Аналіз класичних моделей охорони здоров'я, проведений В. Борщ [1], М. Поворозник [2], М. Співак [3], доводить відсутність досконалої моделі фінансування охорони здоров'я та дає змогу зробити висновок щодо необхідності формування нової системи шляхом поєднання та адаптації оптимальних для вітчизняних умов концептуальних положень різних моделей. Питанням удосконалення системи охорони здоров'я присвятили увагу Т. Ямненко [4], О. Коломієць [5], Н. Мачуга [6], О. Вашев та О. Мазурок [7], водночас діюча система охорони здоров'я перебуває у процесі трансформації, тому виникають нові проблеми у ії функціонуванні, недоліки організації та невивчені ризики реформування.

Формулювання цілей статті. Мета роботи - дослідити організаційно-економічні особливості вітчизняної трансформаційної моделі охорони здоров'я та визначити напрями іï удосконалення.
Виклад основного матеріалу. Оскільки пострадянська система охорони здоров'я під впливом ринкових сил вичерпала свій ресурс розвитку, 30 листопада 2016 року КМУ схвалив Концепцію реформи охорони здоров'я, яку було запущено з січня 2018 року. В основу реформи покладено світовий досвід організації систем фінансування охорони здоров'я (табл. 1).

Вибрана Україною модель державного солідарного медичного страхування тяжіє до іспанської, однак у процесі трансформації виявляються специфічні організаційно-економічні особливості вітчизняної системи, яким притаманні як переваги, так і недоліки.

Досліджуване реформування складається 3 трьох етапів, таких як [8]:

1) формування центрального органу виконавчої влади з метою реалізації державної політики у сфері державних фінансових гарантій медичного обслуговування населення - Національної Служби Здоров'я України. Організація фінансування екстреної, вторинної, третинної, паліативної допомоги та реабілітації згідно з Програмою медичних гарантій;

2) адаптація закладів охорони здоров'я до нових механізмів підпорядкування, функціонування та фінансування;

3) розроблення та прийняття закону про загальнодержавне добровільне медичне страхування. Формування механізмів відносин державного страховика i приватних страхових компаній задля ефективного забезпечення мінімального пакету медичних послуг (на основі пріоритетності) і ширший спектр медичних послуг у межах додаткових страхових програм.

Нині реформа перебуває на другому етапі і вже має як прихильників, так і опонентів серед населення (рис. 1). 
Таблиця 1

Особливості моделей фінансування охорони здоров'я

\begin{tabular}{|c|c|c|}
\hline Модель & Країна-представник & Особливості \\
\hline $\begin{array}{l}\text { Соціально-медичне } \\
\text { страхування } \\
\text { (модель Бісмарка, } \\
\text { страхова модель) }\end{array}$ & $\begin{array}{l}\text { Австрія, Швейцарія, } \\
\text { Ізраїль, Франція, } \\
\text { Нідерланди, держави } \\
\text { Східної Європи та } \\
\text { Прибалтики, Японія тощо. }\end{array}$ & $\begin{array}{l}\text { Більшість закладів охорони здоров’я приватні, оплата медичних послуг } \\
\text { здійснюється фондом страхування працівників, що фінансуються робо- } \\
\text { тодавцями та працівниками (шляхом вирахувань із заробітної плати). } \\
\text { Розподіл медичних ризиків окремих груп громадян на все населення, } \\
\text { державне бюджетне субсидування медичних послуг із загальних або } \\
\text { цільових надходжень }\end{array}$ \\
\hline $\begin{array}{c}\text { Державна } \\
\text { (модель Беверіджа) }\end{array}$ & $\begin{array}{l}\text { Великобританія, Ірландія, } \\
\text { Данія, Фінляндія, Норвегія, } \\
\text { Швеція, Канада, Італія, } \\
\text { Іспанія, Португалія, Греція, } \\
\text { Нова Зеландія }\end{array}$ & $\begin{array}{l}\text { Більшість медичних закладів державні, медичне обслуговування нада- } \\
\text { ється та фінансується урядом за рахунок податків (пацієнт не платить за } \\
\text { медичні послуги) }\end{array}$ \\
\hline $\begin{array}{c}\text { Приватно-підприєм- } \\
\text { ницька (ринкова або } \\
\text { приватна модель) }\end{array}$ & США, Південна Корея & $\begin{array}{l}\text { Медичне забезпечення формується відповідно до фінансових можливос- } \\
\text { тей і потреб населення та за законами вільного ринку. Поєднання при- } \\
\text { ватного страхування } 3 \text { покриттям витрат із суспільних фондів для груп } \\
\text { підвищеного ризику }\end{array}$ \\
\hline $\begin{array}{l}\text { Суспільно-приватна } \\
\text { модель } \\
\text { (змішана форма) }\end{array}$ & Нідерланди, Японія & $\begin{array}{l}\text { Характеризується покриттям витрат на медичну допомогу шляхом поєд- } \\
\text { нання соціального та приватного медичного страхування }\end{array}$ \\
\hline
\end{tabular}

Джерело: складено на основі [1-3]

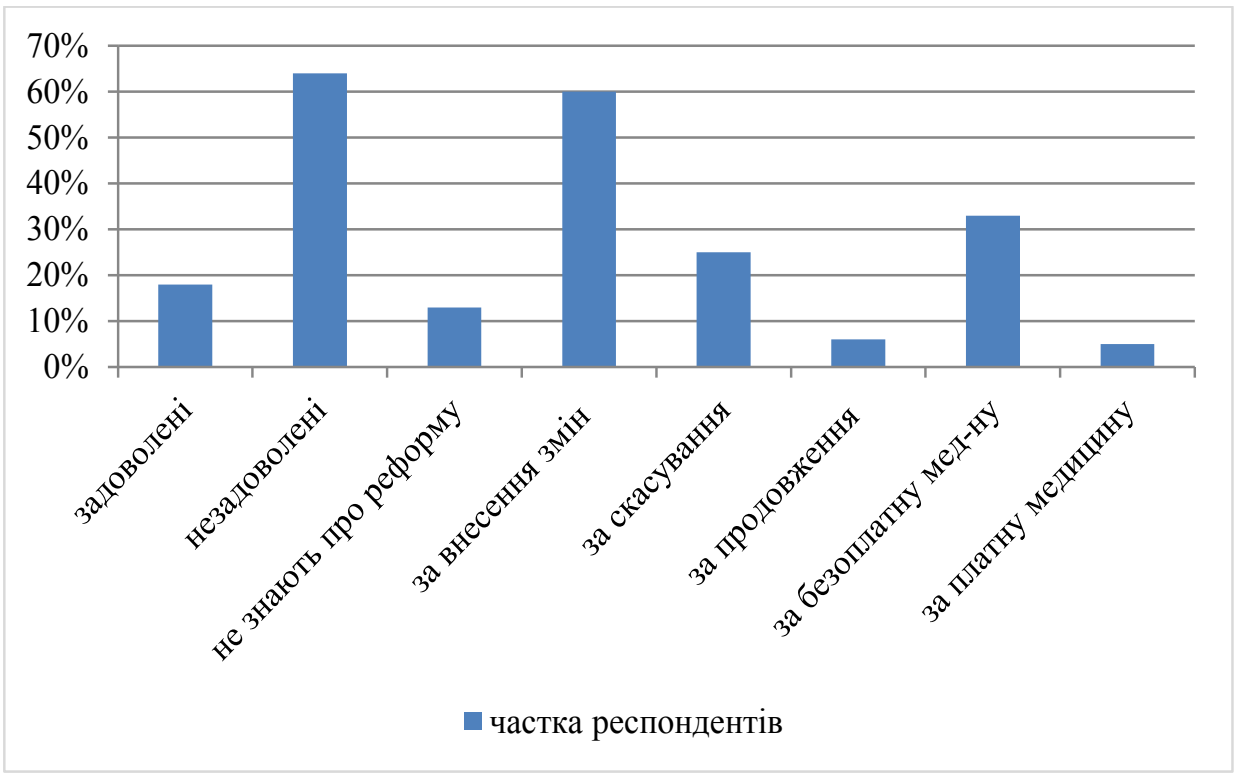

Рис. 1. Результати опитування населення щодо реалізації медичної реформи

Джерело: сформовано на основі [9]

Незадоволеність населення в умовах, що склалися, та проблематика трансформаційної системи охорони здоров'я спонукали до опитування фахівців медичної галузі з метою виявлення переваг та недоліків оновленої моделі. Для формування якісної вибірки в межах методу «Snow-ball» було сформовано ланцюжок респондентів та визначено експертну групу для SWOT-аналізу вітчизняної моделі охорони здоров'я. Результати дали змогу представити підсумкову матрицю сум зважених оцінок експертів (табл. 2) та зробити висновок щодо суперечливих настроїв фахівців медичного сектору.

Найсильнішими сторонами моделі визначено єдині тарифи та самостійність у виборі закладу охорони здоров'я, а також те, що дохід залежить від обсягу роботи, хоча В. Зеленський саме новий механізм фінансування («гроші ходять за пацієнтом») зарахував до недоліків, обгрунтувавши це втратою працевлаштування близько 50 тис. медиками і закриттям 332 лікарень. Задоволеність медичних працівників таким механізмом залежить від місця працевлаштування та одержаного фінансування їхнього закладу у 2019-2020 роках (зокрема, за рахунок грантів).

Найслабшою стороною визначено дефіцит фінансування. Крім того, до матриці не занесено низки слабких позицій, що наявні у процесі трансформації, але згодом мають зникнути, а отже, не є визначальними для функціонування запроваджуваної моделі. До таких 


\begin{tabular}{|c|c|c|c|}
\hline Сильні сторони & $\begin{array}{l}\Sigma \text { зваж. } \\
\text { оцінок }\end{array}$ & Слабкі сторони & $\begin{array}{l}\Sigma \text { зваж. } \\
\text { оцінок }\end{array}$ \\
\hline $\begin{array}{c}\text { принцип «гроші йдуть за пацієнтом» } \\
\text { (дохід залежить від обсягу роботи) }\end{array}$ & 0,8 & $\begin{array}{c}\text { дефіцит фінансування } \\
\text { (урізання тарифів для лікарень) }\end{array}$ & 1,5 \\
\hline $\begin{array}{l}\text { єдині тарифи для оплати медичних послуг та } \\
\text { лікарських засобів для всієї території України }\end{array}$ & 1 & $\begin{array}{c}\text { протитуберкульозна служба, психіатричні лікарні, } \\
\text { екстрена медична допомога та спеціалізовані } \\
\text { медичні напрями недостатньо фінансуються }\end{array}$ & 0,8 \\
\hline $\begin{array}{c}\text { можливість пацієнту самостійно вибирати } \\
\text { заклад охорони здоров’я для отримання } \\
\text { медичної допомоги } \\
\end{array}$ & 1 & $\begin{array}{c}\text { ускладнення фізичного доступу до лікарень для } \\
\text { надання спеціалізованих послуг }\end{array}$ & 0,4 \\
\hline тарифи покриття (100\% покриває держава) & 0,4 & $\begin{array}{c}\text { уповільнення одержання медичних послуг через } \\
\text { необхідність звернення до сімейного лікаря та } \\
\text { обмежені виїзди карети швидкої допомоги }\end{array}$ & 1 \\
\hline реімбурсація (відшкодування) ціни ліків & 0,3 & брак управлінських знань у головних лікарів & 0,1 \\
\hline автономізація медичних закладів & 0,3 & $\begin{array}{c}\text { залежність від одноосібних рішень } \\
\text { головних лікарів }\end{array}$ & 0,1 \\
\hline $\begin{array}{l}\text { створення єдиної системи } \\
\text { електронної охорони здоров'я }\end{array}$ & 0,3 & розрив між попитом і пропозицією & 0,3 \\
\hline Разом & 4,1 & Разом & 4,2 \\
\hline Можливості & $\begin{array}{l}\Sigma \text { зваж. } \\
\text { оцінок }\end{array}$ & Загрози & $\begin{array}{l}\Sigma \text { зваж. } \\
\text { оцінок }\end{array}$ \\
\hline $\begin{array}{c}\text { підвищення якості медичних послуг } \\
\text { під впливом загострення конкуренції } \\
\text { на ринку медичних послуг } \\
\end{array}$ & 0,9 & $\begin{array}{c}\text { недобросовісність страховика } \\
\text { (уникнення зобов'язань щодо оплати лікування } \\
\text { страхувальника, грунтуючись на різних підставах) } \\
\end{array}$ & 1,5 \\
\hline $\begin{array}{c}\text { удосконалення системи контролю } \\
\text { якості медичних послуг }\end{array}$ & 0,2 & $\begin{array}{c}\text { вузький спектр медичних послуг } \\
\text { для малозабезпечених верств населення } \\
\text { згідно з національною системою страхування }\end{array}$ & 1 \\
\hline $\begin{array}{c}\text { альтернативні джерела медичного } \\
\text { фінансування }\end{array}$ & 0,6 & $\begin{array}{c}\text { недосконалість законодавства } \\
\text { з регулювання медичного страхування }\end{array}$ & 0,8 \\
\hline мотивація медичних працівників & 1,5 & $\begin{array}{c}\text { втрата контролю над закладами } \\
\text { первинної медичної допомоги }\end{array}$ & 0,2 \\
\hline $\begin{array}{c}\text { зменшення фінансового навантаження } \\
\text { на населення }\end{array}$ & 0,1 & загострення проблеми кадрового забезпечення & 0,6 \\
\hline Разом & 3,3 & Разом & 4,1 \\
\hline
\end{tabular}

можна віднести: недостатні навички медичного персоналу діяти за новими правилами; проблеми з ліцензуванням; неузгоджене законодавство щодо медицини та повільний Інтернет у селах, що перешкоджає роботі єдиної системи електронної охорони здоров'я; неврегульовані відносини із невідкладною і вторинною допомогою; невирішені організаційні питання щодо виїзду сімейних лікарів на виклики тощо.

Думки щодо ефективності і, відповідно, доцільності поточної медичної реформи розділилися не тільки в населення і медичних працівників, але й у політичних колах.

У [8, с. 2] акцентувалося на важливості політичної підтримки і стабільності дотримання визначеного курсу трансформації для забезпечення повного покриття населення послугами охорони здоров'я, а також наголошувалося на необхідності захищеності фінансування системи охорони здоров'я в межах бюджету. Однак останнім часом обговорювалися варіанти повернення до колишньої системи фінансування, що обурює прихильників реформування, які вважають, що галузь потрібно дофінансовувати, не припиняючи реформи. Поки що реформування продовжується, але проблема фінансування залишається, адже трансфор- мація системи охорони здоров'я відбувається в умовах економічної кризи і пандемії.

Так, в умовах падіння ВВП, за дефіциту державного бюджету 6\% ВВП і запланованого великого зростання ПДВ та інших податків, проект Державного бюджету передбачає збільшення витрат на медицину у 2021 році до 4,2\% ВВП [10]. Закон України [11] передбачає 5\%, але в нинішніх умовах зростання обсягів фінансування охорони здоров'я до цього рівня прогнозується до 2023 року. Тобто поки що в номінальному виразі видатки на охорону здоров'я збільшаться приблизно на $17 \%$, однак не буде фонду для боротьби 3 COVID-19, який нині становить 65 млрд грн. (за очевидних умов, що без вакцини епідемія не вщухне до літа). Згідно $з$ дослідженнями [12], незважаючи на зростання видатків, такі фактори, як COVID-19, інфляція, підвищення мінімальної заробітної плати, додаткові надбавки лікарям, зокрема тим, що борються з COVID-19, залишать низку галузевих зобов'язань невиконаними. Отже, план реформування потребує суттєвого коригування.

3 огляду на виявлені слабкі сторони та ризики вітчизняної моделі державного солідарного медичного 
страхування доцільно звернути увагу на іiі удосконалення за такими напрямами, як:

- нормативно-правовий (закони 3 регулювання медичного страхування, наглядові закони щодо лікування страхувальника; закони щодо прав і відповідальності медичних працівників, запровадження показників якості наданих медичних послуг і контроль якості наданих послуг тощо);

- управлінський (тренінги для адміністрації щодо управління закладом охорони здоров'я в нових господарських умовах, для медичного персоналу - тренінги та організаційно-методичні рекомендації щодо деталізації функціонування нової системи та особливостей роботи в іiі структурі тощо);

- економічний (збалансування поєднання бюджетних і позабюджетних джерел фінансування; стимулювання активізації та розвитку приватного медичного сектору за рахунок зниження ставок оподаткування для бізнесу, що надає дефіцитні медичні послуги; удосконалення механізму державно-приватного партнерства);

- організаційний (узгодження взаємозв'язків між функціональними елементами системи охорони здоров'я, зокрема, медичною сферою, сферою освіти, фінансовими посередниками, а також у структурі медичної сфери, наприклад між невідкладною і вторинною допомогою; розроблення та впровадження програм, спрямованих на покращення кадрової ситуації у сфері медичної допомоги; моніторинг реалізації реформування, виявлення та врахування громадської думки щодо суспільно значущих проблем, наприклад, проект з урегулювання гострого для населення питання 3 виїздами карети швидкої допомоги (йдеться про перегляд екстрених випадків, що обслуговує швидка допомога, або про віднесення підвищення артеріального тиску до екстрених ситуацій задля приїзду швидкої допомоги на такі виклики з метою попередження інсультів, або про надання допомоги в подібних випадках на платній основі тощо).

Висновки. Ефективне реформування системи охорони здоров'я вимагає своєчасної перевірки правильності заданого курсу іï розвитку. Слабкі сторони та ризики діючої моделі можуть бути усунені в межах нормативно-правового, управлінського, економічного та організаційного напрямів удосконалення системи охорони здоров'я. Найгостріше питання фінансування медичної галузі може бути вирішено шляхом диверсифікації джерел фінансових ресурсів, насамперед інноваційних (державно-приватне партнерство, зокрема у формі фасиліті-менеджменту). Усунення виявлених у плануванні недоліків і помилок сприятиме змінам ставлення суспільства до реформування галузі за рахунок мінімізації протиріч в оновленій моделі. Розроблення кількісних індикаторів ефективності функціонування системи охорони здоров'я та механізму їх упровадження цікавлять автора як перспективи подальших досліджень.

\section{Список літератури:}

1. Борщ В.І. Сучасні тенденції розвитку системи охорони здоров’я в Україні: порівняльний аналіз. Економічний вісник Запорізької державної інженерної академії. 2018. Вип. 6. С. 215-221.

2. Поворозник М.Ю. Комплексний аналіз національних моделей організації систем медичних послуг. Причорноморські економічні студї. 2017. Вип. 14. С. 25-28.

3. Співак М.В. Державна політика здоров’язбереження: світовий досвід і Україна : монографія. Київ : Ін-т держави і права ім. В.М. Корецького НАН України; Логос, 2016. 536 с.

4. Ямненко Т.М. Медична реформа: реалії України та міжнародний досвід. Юридичний вісник. Повітряне $i$ космічне право. 2018. № 2. С. 116-120.

5. Коломієць О.О. Система охорони здоров'я в Україні: недоліки організації та ризики реформування. Економічний вісник НТУУ «КПІ»: зб. наук. працьь. 2018. № 15. С. 18-27.

6. Мачуга Н.3. Теорія і методологія функціонування системи надання медичних послуг в Україні: дис. ... д-ра екон. наук: 08.00.03 / Тернопіл. нац. економ. ун-т, Тернопіль, 2016. 386 с.

7. Вашев О.С., Мазурок О.В. Розвиток муніципальної медицини як складова реформування системи охорони здоров’я. Теорія та практика державного управління: зб. наук. пращь. 2015. Вип. 1 (48). С. 101-106.

8. MO3 України: Що було, є і буде / М-во охорони здоров'я України. URL: https://moz.gov.ua/uploads/2/13773transition_book_healthcare.pdf (дата звернення: 14.10.2020).

9. Оцінка медичної сфери. Соціологічна група Рейтинг: веб-сайт. URL: http://ratinggroup.ua/research/ukraine/ ocenka medicinskoy sfery.html?fbclid=IwAR0m4bNlVvOWDHuHbeURyhi2PE3zO6nr2jpUlKtp-CacxdhzLH5xETi46M0

10. Проект Закону про Державний бюджет України на 2021 рік від 14.09.2020 p. № 4000. URL: https://w1.c1.rada. gov.ua/pls/zweb2/webproc4_1?pf3511=69938 (дата звернення: 28.10.2020).

11. Про державні фінансові гарантії медичного обслуговування населення: Закон України від 03.07 .2020 р. № 2168-VIII. Відомості Верховної Ради. 2018. № 5. URL: https://zakon.rada.gov.ua/laws/show/2168-19\#Техt (дата 3вернення: 11.09.2020).

12. Огляд проєкту бюджету 2021. Центр економічної стратегіï: веб-сайт. URL: https://ces.org.ua/draft-budget2021-the-full-text-of-the-press-conference/ (дата звернення: 11.10.2020). 


\section{References:}

1. Borsch V.I. (2018) Suchasni tendentsiyi rozvytku systemy okhorony zdorov'ya v Ukrayini: porivnyal'nyy analiz [Modern trends in the development of the health care system in Ukraine: a comparative analysis]. Economic Bulletin of the Zaporizhye State Engineering Academy, issue 6, pp. 215-221.

2. Povoroznyk M.Yu. (2017) Kompleksnyy analiz natsional'nykh modeley orhanizatsiyi system medychnykh posluh [Complex analysis of national models of organization of medical services systems]. Black Sea Economic Studies, issue 14, pp. 25-28.

3. Spivak M.V. (2016) Derzhavna polityka zdorov'yazberezhennya: svitovyy dosvid i Ukrayina [State policy of health preservation: world experience and Ukraine]. Kyiv: Logos. (in Ukrainian).

4. Yamnenko T.M. (2018) Medychna reforma: realiyi Ukrayiny ta mizhnarodnyy dosvid [Medical reform: realities of Ukraine and international experience]. Yurydychnyy visnyk. Povitryane i kosmichne pravo, no. 2, pp. 116-120.

5. Kolomiets O.O. (2018) Systema okhorony zdorov'ya v Ukrayini: nedoliky orhanizatsiyi ta ryzyky reformuvannya [Health care system in Ukraine: shortcomings of the organization and risks of reform]. Economic Bulletin of NTUU "KPI": coll. of sc. works, no. 15, pp. 18-27.

6. Machuga N.Z. (2016) Teoriya i metodolohiya funktsionuvannya systemy nadannya medychnykh posluh v Ukrayini [Theory and methodology of functioning of system of rendering of medical services in Ukraine] (Dr. of Science thesis), Ternopil: Ternopil National Economic University.

7. Vashev O.E., Mazurok O.V. (2015) Rozvytok munitsypal'noyi medytsyny yak skladova reformuvannya systemy okhorony zdorov'ya [Development of municipal medicine as a component of health care reform]. Theory and practice of public administration: coll. of sc. works, issue 1 (48), pp. 101-106.

8. Ministry of Health of Ukraine (2018) MOZ Ukrayiny: Shcho bulo, ye i bude [Ministry of Health of Ukraine: What was, is and will be]. URL: https://moz.gov.ua/uploads/2/13773-transition_book_healthcare.pdf (Accessed 14 October 2020).

9. Sociological group Rating (2020) Otsinka medychnoyi sfery [Evaluation of the medical field]. Available at: http://ratinggroup.ua/research/ukraine/ocenka_medicinskoy_sfery.html?fbclid=IwAR0m4bNIVvOWDHuHbeURyhi2PE3z O6nr2jpUlKtp-CacxdhzLH5xETi46M0 (accessed 08 October 2020).

10. The Verkhovna Rada of Ukraine (2020) Proekt Zakonu pro Derzhavnyy byudzhet Ukrayiny na 2021 rik [Draft Law on the State Budget of Ukraine for 2021]. Available at: https://w1.c1.rada.gov.ua/pls/zweb2/webproc4 1?pf3511=69938 (accessed 28 October 2020).

11. The Verkhovna Rada of Ukraine (2020) Pro derzhavni finansovi harantiyi medychnoho obsluhovuvannya naselennya: Zakon Ukrayiny [The Law of Ukraine About the state financial guarantees of medical service of the population]. Available at: https://zakon.rada.gov.ua/laws/show/2168-19\#Text (accessed 11 September 2020).

12. Center for Economic Strategy (2020) Ohlyad proyektu byudzhetu 2021 [Review of the draft budget 2021]. Available at: https://ces.org.ua/draft-budget-2021-the-full-text-of-the-press-conference/ (accessed 11 October 2020).

\section{ОРГАНИЗАЦИОННО-ЭКОНОМИЧЕСКИЕ ОСОБЕННОСТИ ТРАНСФОРМАЦИОННОЙ МОДЕЛИ ЗДРАВООХРАНЕНИЯ УКРАИНЫ}

В статье рассмотрен мировой опыт организачии систем финансирования здравоохранения $и$ этапы реформирования отечественной модели предоставления медицинских услуг. Обобщены результаты опроса населения по отношению к реализации медицинской реформы. Проведен SWOT-анализ отечественной трансформационной модели государственного солидарного медииинского страхования, в результате чего определены организационно-экономические особенности, преимущества и недостатки действующей системь здравоохранения Украины. Выявлены сильные и слабые стороны отечественной модели, а также ее временные проблемы. Рассмотрены причины недостаточного финансирования медицинской отрасли и сделан вывод о необходимости корректировки плана реформирования. Определены направления и намечень основные пути совершенствования действующей системы здравоохранения за счет минимизации противоречий в обновленной модели.

Ключевые слова: здравоохранение, модель, финансирование, SWOT-анализ, направления совершенствования.

\section{ORGANIZATIONAL AND ECONOMIC FEATURES OF THE TRANSFORMATION MODEL OF HEALTHCARE OF UKRAINE}

The increasing importance of human potential in the economic development of the country focuses attention on health problems as a priority area for the activities of society and the state. However, the conflicting nature of the current model of health care in Ukraine, along with meeting the growing needs for medical services on the principles of equality and justice, is revealed in the limited financial and economic capabilities of the public sector. This updated the study of the features of the transformational model of health care in Ukraine. The article examines the world experience of organizing health care financing systems, which allows us to conclude that there is no perfect model for health financing and emphasizes the need to form a new system by combining and adapting conceptual provisions of vari- 
ous models that are optimal for domestic conditions. The next step in the work considered the stages of reforming the domestic model of providing medical services, which served as a prerequisite for analyzing the process of reforming the medical industry. The paper summarizes the results of a survey of the population in relation to the implementation of medical reform, which made it possible to identify its supporters and categories of the population opposed to the reform or for its completion. The analysis of the domestic transformational model of state solidarity health insurance is carried out; the SWOT-matrix of the sums of weighted assessments of experts is formed, which allows us to conclude about the conflicting moods of specialists in the medical sector. As a result of the analysis, organizational and economic features, advantages and disadvantages of the current health care system of Ukraine have been identified. The strengths and weaknesses of the domestic model, as well as its temporary problems, have been identified. The reasons for the insufficient financing of the medical industry are considered and the conclusion is made about the need to adjust the reform plan. The directions are determined and the main ways of improving the current health care system are outlined by minimizing contradictions in the updated model.

Key words: healthcare, model, financing, SWOT-analysis, areas of improvement. 